\title{
1 DIFRUCTOSE ANHYDRIDES AS QUALITY MARKERS OF HONEY AND
}

2 COFFEE.

3 A. Montilla ${ }^{1}$, A.I. Ruiz- Matute ${ }^{2}$, M.L. Sanz ${ }^{2 *}$, I. Martínez-Castro ${ }^{2}$, M.D. del Castillo ${ }^{1}$

4

5

6

7

8

$9{ }^{1}$ Instituto de Fermentaciones Industriales (C.S.I.C.)

$10 \quad{ }^{2}$ Instituto de Química Orgánica General (C.S.I.C.)

11 c/Juan de la Cierva, 328006 Madrid (Spain)

12

13

14 *Telephone : +34915622900

15 Fax: + 34915644853

16 Email: mlsanz@iqog.csic.es

17

18

19

20 Abbreviated running head: Difructose anhydrides in honey and coffee

21

22

23

24

25 


\section{ABSTRACT}

Difructose anhydrides (DFAs) are pseudodisaccharides produced by condensation of two fructose molecules by means of caramelization reaction which 30 takes place during heating of sugars or sugar-rich foodstuffs. The aim of this research 31 was to evaluate the feasibility of DFAs as chemical markers of honey authenticity and sugar-roasted torrefacto coffee. DFAs were analysed by gas chromatography coupled to mass spectrometry after conversion to their trimethylsilyl (TMS) derivatives. $\alpha$-Dfructofuranoside-1,2':2,1'- $\alpha$-D-fructofuranoside (DFA7) and $\alpha$-D-fructofuranoside$1,2^{\prime}: 2,1^{\prime}-\beta$-D-fructopyranoside (DFA9) can be used as quality markers of honey and 36 coffee. DFA7 and DFA9 were detected in honey added with 5\% fructose and sucrose caramels and $15 \%$ of glucose caramels. Torrefacto coffees showed DFAs values ranged from 0.195 to $0.570 \mathrm{~g} / 100 \mathrm{~g}$ whereas only traces were found in natural roasted coffees. Quantities from 0.073 to $0.189 \mathrm{~g} / 100 \mathrm{~g}$ were measured in blends of natural and 40 torrefacto roasted coffees. A relationship between DFAs content in torrefacto coffees and roasting conditions was observed. In conclusion, this study indicated that DFAs are useful chemical indicators to control honey authenticity and torrefacto coffee roasting.

47 KEYWORDS: Difructose anhydrides, caramelization, honey, coffee, authenticity, torrefacto. 


\section{INTRODUCTION}

In recent times, food quality assurance is getting a great importance for consumers, producers and regulatory authorities. Food quality requires the control of nutritional value, sensorial properties, authenticity and safety. Various chemical compounds can be used as quality markers. By definition, good chemical indicators of quality may be considered those natural food components which concentrations are modified during processing such as proteins, fats, or aminoacids; those formed during processing and storage, or those incorporated to foods as contaminants and adulterants (Lee and King, 1996). Carbohydrate breakdown products formed by isomerization, Maillard and caramelization reactions have been widely employed as very good markers of quality in a great number of processed foods (Corzo, Delgado, Troyano, Olano, 1994; Sanz, del Castillo, Corzo, Olano, 2000).

Difructose anhydrides (DFAs) are pseudodisaccharides formed during caramelization reaction consisting of two fructose residues and possessing physiological functions (Manley-Harris \& Richards, 1997; Saito, Tomita, 2000). This reaction takes place during heating of sugars or food products rich in sugars, and results in a minor volatile fraction and a major proportion of non-volatile components (90-95\%) including DFAs. The relative proportion of DFAs depends on food composition and processing (Defaye, Fernandez, Ratsimba, 2000). DFAs analysis in caramels was first described by Tschiersky and Baltes (1989) and more studies have been conducted to give insight to their chemical structure (Defaye \& García-Fernández, 1994; Defaye \& GarcíaFernández, 1995). Methodologies have been settled for analysis of DFAs as suitable tracers of caramelization in food and food additives as caramels, chicory and dehydrated fruits (Defaye et al., 2000). DFA content in caramels prepared from fructose, glucose and sucrose may be determined by gas chromatography-mass spectrometry (GC-MS) of 
their trimethylsilyl (TMS) derivatives (Ratsimba, Fernandez, Defaye, Nigay, Voilley, 76 1999).

Honey is a natural food elaborated by honeybees either from nectar of blossoms (nectar honey) or from secretions of living parts of plants or excretions of plant sucking 79 insects on the living part of plants (honeydew honey). Honeydew honeys usually have 80 darker colours than nectar honeys and in many areas are more valued than these ones 81 (Prodolliet \& Hischenhuber, 1998). There are evidences of honey frauds by caramels 82 addition to nectar honeys to enhance their colour. Detection of honey adulteration is not 83 always easy and represents a problem to solve. DFA analysis by GC may provide an 84 inexpensive easy adequate approach to be employed for the routine quality control of 85 this food.

86 beans because it strongly affects taste, acidity, body, aroma and flavour. Coffee beans 88 may be roasted following two main ways known as "conventional or natural" without 89 90 sugar addition and "torrefacto" when sugar is added. The roasting degree in each country is determined by preferences of consumers. In general, North European countries mainly consume light-roasted, American medium-roasted and South European countries dark-roasted coffees; some South American countries, Portugal and Spain mainly consume blends of natural and torrefacto coffees (Maetzu, Andueza, Ibáñez, de 94 Peña, Bello, Cid, 2001). Natural and torrefacto roasted coffee present differences in the 95 96

97 volatile fraction perceived by sensorial analysis in the intensities of the nutty, roasty, earthy, burnt and caramel notes (Sanz, Meatzu, Zapelena, Bello, Cid, 2002). Torrefacto roasting also contributes to the brownish colour of the coffee brew (Maetzu et al., 98 2001). 
Very few references related to quality control of torrefacto coffees are available.

As it is known, Arabica coffees are more valued by consumers than Robusta coffees because their sensorial properties. Previous studies have observed that torrefacto roasting mask the poor sensorial properties of Robusta coffee (Maetzu et al., 2001) and could be used as a fraud. The influence of torrefacto roasting on the volatile fraction of coffee and its sensorial properties has been described (Sanz et al., 2002); however, studies related to the non-volatile compounds formed by caramelization in this type of coffee have not been conducted yet. Therefore, since caramelization takes place during torrefacto roasting, DFAs may be formed and provide useful information related to the degree of torrefacto roasting and the composition of blends.

In our knowledge, DFAs have not been previously determined either in honey or in torrefacto coffee. Consequently, the aim of this research was to find out the feasibility of DFAs as chemical indicators of honey authenticity and control torrefacto roasting.

113 MATERIALS AND METHODS

114 Reagents

115 Glucose, fructose, sucrose and phenyl- $\beta$-glucoside were acquired from Sigma

116 (St. Louis, USA). High-purity water was produced in-house using a Milli-Q Synthesis

117 A10 system (Millipore, Bellerica, Mass., USA) and was used throughout.

119 Samples

120 Honey samples ( $\mathrm{n}=20)$ : 16 nectar honeys from different botanical origins (citrus, 121 rosemary, heather, acacia, eucalyptus and multifloral) and 4 honeydew honeys were 122 purchased to beekeepers and local markets. 
124 including 20N/80T $(\mathrm{n}=1), 30 \mathrm{~N} / 70 \mathrm{~T}(\mathrm{n}=1)$ and 50N/50T $(\mathrm{n}=5)$, from industrial brands were purchased at local markets. In order to evaluate the influence of roasting on DFAs formation, Arabica coffee

127 beans were roasted under controlled conditions by a coffee company (Café La 128 Mexicana, Rodríguez y Mateus, S.A Madrid) to obtain 3 natural and 2 torrefacto

129 coffees. Natural roasting was carried out at temperatures ranged from $150^{\circ} \mathrm{C}$ to $198^{\circ} \mathrm{C}$

130 for $15 \mathrm{~min}$. Torrefacto coffees were obtained adding sugar to Arabica beans during

131 roasting at $203-214^{\circ} \mathrm{C}$ for $18 \mathrm{~min}$. In addition, coffee blends (20N/80T $(\mathrm{n}=1), 30 \mathrm{~N} / 70 \mathrm{~T}$

$132(\mathrm{n}=1)$ and 50N/50T $(\mathrm{n}=1))$ were produced in the laboratory from commercial coffees

133 having known DFA contents. A comparative analysis of DFAs values obtained for 134 commercial and produced in-house blends was carried out.

\section{Sample preparation}

Acid caramels:

$10 \mathrm{~g}$ of glucose, fructose and sucrose were separately mixed with $0.1 \mathrm{~g}$ of citric

140 acid and $1 \mathrm{~mL}$ of water and heated at $160^{\circ} \mathrm{C}$ for 150 minutes, $140^{\circ} \mathrm{C}$ for 35 min and

$141140^{\circ} \mathrm{C}$ for $25 \mathrm{~min}$, respectively. $3 \mathrm{~mL}$ of additional water were added to each sample at

142 the end of the cooking process and heated for two minutes at the same temperatures.

143 Honey

144 Acacia honey was added with 5,10 and 15\% of caramel. Caramels and honey samples $(0.5 \mathrm{~g})$ were diluted to $25 \mathrm{~mL}$ with $70 \%$ methanol, prior to DFAs analysis. 
Hot water $\left(75^{\circ} \mathrm{C}, 60 \mathrm{~mL}\right)$ was added to ground coffee $(10 \mathrm{~g})$, stirred for $5 \mathrm{~min}$ and

148 filtered through Whatman no.4 filter paper. $3 \mathrm{~mL}$ of filtrates were deproteinated and

149 defatted by stirring with $25 \mathrm{~mL}$ of methanol followed by standing for at least $1 \mathrm{~h}$. The

150 clear supernatants obtained were employed for DFAs analysis.

\section{Analytical methods}

153 All analyses were carried out in duplicate.

Gas chromatography analysis

Methanol solutions of caramels $(0.5 \mathrm{~mL})$, honey $(0.5 \mathrm{~mL})$ and coffees $(2 \mathrm{~mL})$ were derivatised, prior to $\mathrm{GC}$ analysis. $0.5 \mathrm{~mL}$ of $1 \mathrm{mg} / \mathrm{mL}$ phenyl- $\beta$-D-glucoside, internal standard, was added to the samples. Afterwards, methanol was evaporated under vacuum at $38-40{ }^{\circ} \mathrm{C} .2 .5 \%$ Hydroxylamine chloride in pyridine $(350 \mu \mathrm{L})$ was added to

160 the dry samples and kept at $75^{\circ} \mathrm{C}$ for $30 \mathrm{~min}$. The oximes obtained in this step were

161 silylated with hexamethyldisilazane $(350 \mu \mathrm{L})$ and trifluoroacetic acid $(35 \mu \mathrm{L})$ and kept at $16245^{\circ} \mathrm{C}$ for $30 \mathrm{~min}$ (Brobs and Lott, 1966). The mixtures of reaction were centrifuged at $1637000 \mathrm{~g}$ at $5^{\circ} \mathrm{C}$ for $5 \mathrm{~min}$ (Li and Schumman, 1981; Baños, Olano, Corzo, 2000). The 164 supernatants containing TMS-DFAs were either directly injected or stored at $4^{\circ} \mathrm{C}$ until 165 analysis.

166 GC was performed with a Hewlett-Packard gas chromatograph (HP6890) 167 equipped with a flame ionisation detector (FID). A $25 \mathrm{~m} \times 0.25 \mathrm{~mm} \times 0.25 \mu \mathrm{m}$ fused 168 silica column coated with CP-SIL 5CB (methyl silicone from Chrompack, Middelburg, 169 The Netherlands) was used. The carrier gas (nitrogen) flow rate was $1.2 \mathrm{~mL} / \mathrm{min}$. 170 Injector and detector temperatures were $300^{\circ} \mathrm{C}$. Oven temperature was programmed as 
171 follows: ramp from $180^{\circ} \mathrm{C}$ to $200^{\circ} \mathrm{C}$ at $5^{\circ} \mathrm{C} / \mathrm{min}$, hold for $10 \mathrm{~min}$, ramp to $270^{\circ} \mathrm{C}$ at

$1725^{\circ} \mathrm{C} / \mathrm{min}$, ramp to $282^{\circ} \mathrm{C}$ at $1^{\circ} \mathrm{C} / \mathrm{min}$, ramp to 290 at $15^{\circ} \mathrm{C} / \mathrm{min}$ and hold for $25 \mathrm{~min}$.

173 Samples were injected in split mode (split flow $48 \mathrm{~mL} / \mathrm{min}$ ). An HPChemStation

174 acquisition system (Hewlett-Packard, Palo Alto, CA, USA) was employed.

175 DFAs concentrations were directly estimated from the areas of peaks and

176 internal standard. Results were expressed as $\mathrm{g}$ of DFAs/100 $\mathrm{g}$ of product.

177

178

Mass spectrometry analysis

A HP-5890 chromatograph coupled to a MD 5971 quadrupole mass detector

180 (Hewlett-Packard, Palo Alto, CA, USA) was employed. DFAs separation was

181 performed under the same chromatographic conditions described above. Helium was

182 used as carrier gas. Samples were injected in split mode $(40 \mathrm{~mL} / \mathrm{min})$. Mass

183 spectrometer was operated in EI mode at $70 \mathrm{eV}$. Mass spectra were acquired using a

184 HP-G1034C MS ChemStation software (Hewlett-Packard, Palo Alto, CA, USA).

185

186

Browning development

187

Brown pigments were measured in caramel $(100 \mathrm{mg} / \mathrm{mL})$, honey $(100 \mathrm{mg} / \mathrm{mL})$ and coffee $(10 \mathrm{mg} / \mathrm{mL})$ samples according to Meydav, Saguy \& Kopelman, (1977) by measuring of the absorbance values at $420 \mathrm{~nm}$. This measurement is employed as convenient index of the development of caramelization and Maillard reactions.

192 RESULTS AND DISCUSSION

193 Caramels

194 Glucose, fructose and sucrose caramels were analysed by GC-MS.

195 Chromatographic profiles were similar to those reported by Manley-Harris and Richards 
196 (1996) and Ratsimba et al. (1999). Peaks were numbered according to the last authors.

197 Mass spectrometric analysis confirmed those peaks eluting from 26 to $31 \mathrm{~min}$ 198 corresponded to DFAs, excepting that with retention time of 30.1 min which was 199 assigned as a mixture of DFA10 and sucrose. Thirteen DFA peaks were detected in 200 fructose and sucrose caramels and only five peaks in glucose caramel. DFAs with 201 retention times of $26 \mathrm{~min}$ (DFA1), 29.5min (DFA 7), $29.9 \mathrm{~min}$ (DFA 9) and $30.1 \mathrm{~min}$ 202 (DFA 10) were detected in all caramels. Therefore, only DFA 7 and DFA 9, eluting without chromatographic interferences and in relatively high amount, were employed 204 for quantitative purposes. DFAs 7 and 9 were previously assigned as $\alpha$-D205 fructofuranoside-1,2':2,1'- $\alpha$-D-fructofuranoside and $\alpha$-D-fructofuranoside-1,2':2,1'- $\beta$ 206 D-fructopyranoside by Ratsimba et al. (1999). Figure 1 shows their structures and table 2071 summarizes the main ions obtained by MS for both compounds in caramels. As occur 208 in disaccharides, the same fragments are found in all the series, and compounds have to 209 be distinguished on the basis of retention time and abundance ratios. Fragments at low $210 \mathrm{~m} / \mathrm{z}$ values (less than 190) have in general few diagnostic values. A big fragment at 217

211 (TMSO-CH=CH-CH=OTMS including carbons 1-2-3) indicates two furanose rings, 212 whereas similar abundance of 217 and 204 ions (TMSO-CH=CH-OTMS including 213 carbons 2 and 3) reveals the presence of both furanose and pyranose rings. DFAs 214 spectra are clearly different from those of disaccharides which present a higher 361 ion $215\left(\mathrm{C}_{13} \mathrm{H}_{33} \mathrm{O}_{4} \mathrm{SI}_{3}\right)$. Results agreed with those published by Manley Harris and Richards $216(1992,1997)$.

217 Table 2 shows DFAs content of caramels. Glucose caramel showed the lowest 218 amounts of these compounds (0.15g DFA7/100g caramel and $0.09 \mathrm{~g}$ DFA9/100g 219 caramel) and fructose caramel the greatest values (3.93g DFA7/100g caramel and 9.49g 220 DFA9/100g caramel) as previously reported by Ratsimba et al. (1999) for DFA 9. 
222

223

224

225

226

227

228

229

230

231

232

233

234

235

236

237

238

239

240

241

242

243

244

245

\section{Honey adulteration}

Figure 2 presents the chromatographic profiles of an acacia genuine honey and its adulteration with glucose, fructose and sucrose caramels. DFA7 and DFA9 contents of the samples under study are shown in table 2. DFAs were not detected in the genuine honey sample and in the sample adulterated with 5\% glucose caramel. However, DFAs could be measured in $10 \%$ glucose caramel additions. Adulterations of 5\% fructose and sucrose caramels were easily detected as DFAs. Contents of these compounds progressively increased with the higher addition of acid caramels.

Moreover, absorbance values at $420 \mathrm{~nm}$ of all studied samples were also evaluated. A slight increase of absorbance as a function of caramel addition was observed in honey sample $\left(\mathrm{A}_{420 \mathrm{~nm}} 0.10\right)$. Values of absorbance of $0.19,0.25$ and 0.37 were obtained adding $15 \%$ of glucose, sucrose and fructose caramels, respectively.

Nineteen quality guaranteed honeys of different botanical origins were also analysed to determine if presence of DFAs could be observed in these samples. Absence of these compounds was found in all the analyzed honeys. Therefore, these compounds could be suggested as chemical markers of adulteration of honeys with acid caramels.

\section{Coffee quality}

Figure 3 shows the GC chromatograms acquired for natural, torrefacto and blended (20N/80T) coffees. DFA values obtained for the studied coffee samples are given in Table 3. Very small quantities of DFAs were found in conventionally roasted coffees $(0.010-0.016 \mathrm{~g}$ DFA7/100g and $0.000-0.006 \mathrm{~g}$ DFA9/100g), intermediate in coffee blends $(0.047-0.137 \mathrm{~g}$ DFA7 $/ 100 \mathrm{~g}$ and $0.024-0.053 \mathrm{~g}$ DFA9/100g) and the greatest values in torrefacto coffees $(0.114-0.403 \mathrm{~g}$ DFA7/100g and $0.081-0.167 \mathrm{~g}$ 
DFA9/100g). No linear relationship between torrefacto content and DFAs values were observed for commercial coffee blends, probably due to different manufacture practices. In general, data obtained for the samples produced under controlled conditions agreed with that obtained for commercial samples. All natural conventionally roasted coffees under study ( 6 purchased at the local markets and 3 produced by the coffee company under controlled conditions) showed similar DFAs contents. Different DFAs values were detected in torrefacto coffees purchased at local market and those roasted at $204-213^{\circ} \mathrm{C}$ for $18 \mathrm{~min}$. Differences in quantity of sugar added to coffee beans during roasting and the employed roasting conditions in each case may explain these results.

As can be observed by analysis of absorbance (Table 3), the greatest production of brown pigments took place under torrefacto conditions; intermediate values were obtained for coffee blends and lower for natural roast coffees. Blends data indicated a good relationship between percentage of torrefacto and colour. In general, absorbance data agreed with DFAs values; however, absorbance values obtained for natural and blended coffees $(20 \mathrm{~T} / 80 \mathrm{~N})$ are quite similar. Caramelization of sugar contributes to the

261 brownish colour of the torrefacto coffee brews (Maeztu et al., 2001); however sugar

262 caramelization is not the unique responsible for that. The influence of the conventional roasting on the melanoidin formation (brown pigments) has been previously studied and demonstrated (Ottinger and Hoffman, 2001). Therefore, coffee colour is not a good parameter to discriminate coffee blends $(20 \mathrm{~T} / 80 \mathrm{~N})$ from natural roasted coffees. DFAs may be employed as an adequate indicator of coffee quality in order to avoid frauds or

267 torrefacto addition to mask poor beans quality and to determine the degree of torrefacto 268 roasting. 
1. Baños, J.L.G., Olano, A., \& Corzo, N. (2000) Determination of mono and disaccharide content of enteral formulations by gas chromatography. Chromatographia 52 (3-4), 221-224.

2. Brobst, K.M., \& Lott, C.E. (1966) Determination of some components in corn syrup by gas-liquid chromatography of trimethylsilyl derivatives. Cereal Chemistry 43, 35-43.

3. Corzo, N., Delgado, T., Troyano

E. \& Olano,

A. (1994)

Ratio of lactulose to furosine as indicator of quality of commercial milks Journal of Food Protection 57 (8), 737-739.

4. Defaye, J., \& García Fernández, J.M. (1994) Protonic and thermal-activation of sucrose and the oligosaccharide composition of caramel Carbohydrate Research, 256 (2) C1-C4.

5. Defaye, J., \& García Fernández, J.M. (1995) The oligosaccharide components of caramel. Zuckerindustrie 120 (8), 700-704.

6. Defaye, J., García Fernández, J.M., \& Ratsimba, V. (2000) Les molecules de la caramelization: structure et méthodologies de détection et d'évaluation L'actualité chimique. Novembre 24-27.

7. Lee, T.C. \& King, H.J. (1996) Preface. In: Chemical markers for processed and stored foods. Lee T.C., Kim, H.J. (eds) pp. ix-xi.

290 8. Li, B.W., \& P.J. Schumann. (1981) Gas chromatographic analysis of sugars in granola cereals Journal of Food Science 46: 425-427.

9. Maetzu, L., Andueza, S., Ibáñez, C., de Peña, M. P., Bello, J. \& Cid, C. (2001) 
from different botanical varieties and types of roars by foam, taste, and mouthfeel Journal of Agricultural and Food Chemistry 49: 4743-4747.

10. Manley-Harris, M., \& Richards, G.N. (1992) Mass spectra of some di-D-fructose dianhydride derivatives Carbohydrate Research 226: 327-330.

11. Manley-Harris, M., \& Richards, G.N. (1996) Di-D-fructose dianhydride and related oligosmers from thermal treatments of inulin and sucrose. Carbohydrate Research 287: 183-202.

12. Manley-Harris, M. \& Richards, G.N (1997) Dihexulose dianhydrides. Advances in Carbohydrate Chemistry and Biochemistry 52, 207-266

13. Meydav, S., Saguy, I. and Kopelman, I.J. (1977) Browning determination in citrus products. Journal of Agricultural and Food Chemistry 25: 602-604.

14. Prodolliet, J., \& Hischenhuber, C. (1998) Food authentication by carbohydrate chromatography Zeitschrift fur Lebensmittel-Untersuchung und -Forschung A. 207, 1-12.

15. Ottinger, H. \& Hoffman, T. (2001). Influence of roasting on the melanoidin spectrum in coffee beans and instant coffee. Melanoidins in Food and Health. Volume 2. Office for Publications of the European Communities, Luxembourg, pp119-125. Qualitative and quantitative evaluation of mono- and disaccharides in D-fructose, D-glucose and sucrose caramels by gas-liquid chromatography-mass spectrometry. Di-D-fructose anhydrides as tracers of caramel authenticity. Journal of Chromatography A 844, 283-293. 
317 17. Saito, K., \& Tomita, F. (2000) Difructose anhydrides: their mass-production and 318 physiological functions. Bioscience Biotechnology and Biochemistry 64 (7), 1321$319 \quad 1327$

320 18. Sanz, M.L., del Castillo, M.D., Corzo, N. \& Olano, A. (2000) Presence of 2321 Furoylmethyl Derivatives in Hydrolysates of Processed Tomato Products Journal 322 of the Agriculture and Food Chemistry 48, 468-471.

323 19. Sanz, C., Maeztu, L., Zapelena, M.J., Bello, J., \& Cid, C. (2002) Profiles of 324 volatile compounds and sensory analysis of three blends of coffee: influence of 325 different proportions of Arabica and Robusta and influence of roasting coffee with 326 sugar Journal of the Science of Food and Agriculture 8, 840-847.

327 20. Tschiersky, H., \& Baltes, W. (1989) Investigations of caramel - curiepoint 328 pyrolysis of caramel syrups and other investigations of structure. Zeitschrift fur 329 Lebensmittel-Untersuchung und-Forschung 189, 132 .

330 
332 Table 1. Characteristic ion pattern of trimethylsilylated DFA7 and DFA9.

\begin{tabular}{ccc}
\hline & \multicolumn{3}{c}{ Abundance (\%) } \\
\hline $\mathrm{m} / \mathrm{z}$ & DFA 7 & DFA9 \\
\hline 73 & 91.0 & 100.0 \\
75 & 73.7 & 27.9 \\
103 & 19.4 & 15.9 \\
129 & 14.5 & 16.5 \\
147 & 21.8 & 33.0 \\
169 & 8.1 & 5.9 \\
191 & 2.6 & 2.9 \\
204 & 3.0 & 58.2 \\
217 & 100.0 & 66.7 \\
218 & 17.7 & 13.8 \\
230 & 5.7 & 3.9 \\
361 & 0.1 & 0.2 \\
362 & 0.3 & 0.6 \\
509 & 0.5 & 0.6 \\
510 & 0.3 & 0.3 \\
\hline & &
\end{tabular}

333 
334 Table 2. DFA7 and DFA9 content $(\mathrm{n}=2)$ in caramels and honeys $(\mathrm{g} / 100 \mathrm{~g}$ product $)$.

335

336

\begin{tabular}{ccc}
\hline Sample & DFA7 & DFA9 \\
\hline Glucose caramel (GAC) & $0.15(0.03)^{*}$ & $0.09(0.01)$ \\
Fructose caramel (FAC) & $3.93(0.23)$ & $9.49(0.74)$ \\
Sucrose caramel (SAC) & $1.68(0.11)$ & $2.77(0.19)$ \\
Genuine honey & 0.00 & 0.00 \\
Honey +5\% GAC & 0.00 & 0.00 \\
Honey + 10\% GAC & $0.01(0.00)$ & $0.01(0.00)$ \\
Honey + 15\% GAC & $0.02(0.00)$ & $0.02(0.00)$ \\
Honey +5\% FAC & $0.19(0.08)$ & $0.48(0.10)$ \\
Honey + 10\% FAC & $0.36(0.01)$ & $1.00(0.00)$ \\
Honey + 15\% FAC & $0.60(0.03)$ & $1.55(0.04)$ \\
Honey +5\% SAC & $0.08(0.01)$ & $0.14(0.01)$ \\
Honey + 10\% SAC & $0.15(0.02)$ & $0.28(0.02)$ \\
Honey + 15\% SAC & $0.24(0.03)$ & $0.41(0.02)$
\end{tabular}

* Standard deviation in brackets

338

339

340 Table 3. DFAs content expressed as g/100g product and absorbance measure at 420nm

341 of roasted coffees.

\begin{tabular}{lccc}
\hline \multicolumn{1}{c}{ Samples } & DFA7 & DFA9 & Absorbance 420nm \\
\hline \multicolumn{2}{c}{ Commercial samples } & \\
\hline Natural roast $(\mathrm{n}=6)$ & $0.013(0.002)^{*}$ & 0.000 & $1.17(0.22)$ \\
Torrefacto roast $(\mathrm{n}=4)$ & $0.236(0.010)$ & $0.108(0.026)$ & $2.57(0.42)$ \\
Blends & & & \\
20/80 $(\mathrm{n}=1)$ & $0.062(0.010)$ & $0.024(0.001)$ & $1.49(0.01)$ \\
$30 / 70(\mathrm{n}=1)$ & $0.047(0.004)$ & $0.026(0.007)$ & $1.63(0.07)$ \\
$50 / 50(\mathrm{n}=5)$ & $0.088(0.032)$ & $0.037(0.010)$ & $1.83(0.04)$ \\
\hline & Samples produced under known conditions & \\
\hline Natural roast $(\mathrm{n}=3)$ & $0.014(0.010)$ & $0.05(0.000)$ & $0.83(0.03)$ \\
Torrefacto roast $(\mathrm{n}=2)$ & $0.376(0.038)$ & $0.154(0.018)$ & $2.54(0.10)$ \\
Blends & & & \\
20/80 $(\mathrm{n}=1)$ & $0.071(0.020)$ & $0.029(0.004)$ & $1.27(0.02)$ \\
$30 / 70(\mathrm{n}=1)$ & $0.113(0.010)$ & $0.048(0.010)$ & $1.35(0.01)$ \\
$50 / 50(\mathrm{n}=1)$ & $0.168(0.010)$ & $0.074(0.000)$ & $1.43(0.02)$ \\
\hline
\end{tabular}

* Standard deviation in brackets 
Figure 1.- Structural drawings of DFA 7 and DFA 9.

346

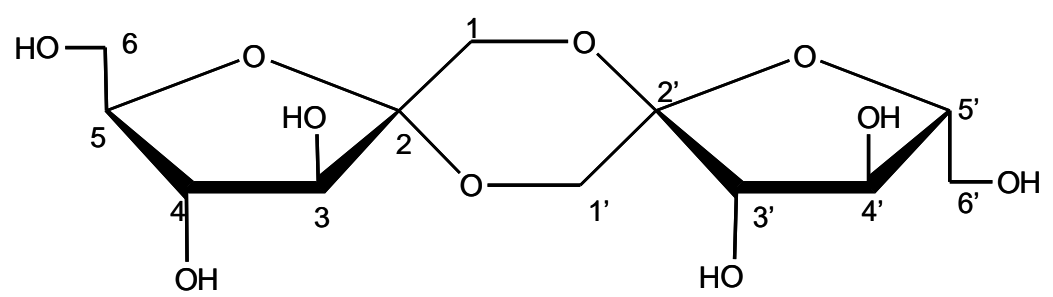

DFA 7 ( $\alpha$-D-fructofuranoside-1,2':2,1'- $\alpha$-D-fructofuranoside)

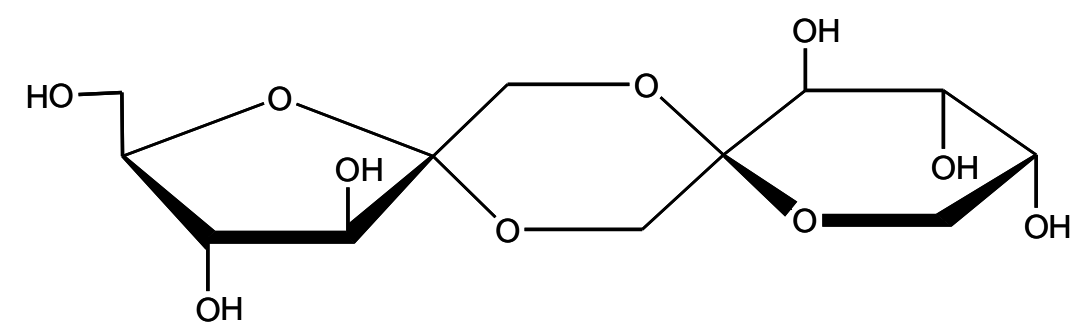

DFA 9 ( $\alpha$-D-fructofuranoside-1,2':2,1'- $\beta$-D-fructopyranoside) 
349 Figure 2.- Gas chromatographic profiles of genuine honey (A) and honey adulterated 350 with $5 \%$ fructose (B), $10 \%$ glucose (C) and 5\% sucrose (D) caramels. (1) phenyl $\beta$ - D 351 glucoside (internal standard), (2) DFA7 (3) DFA9, (4) sucrose, (5) DFA10.
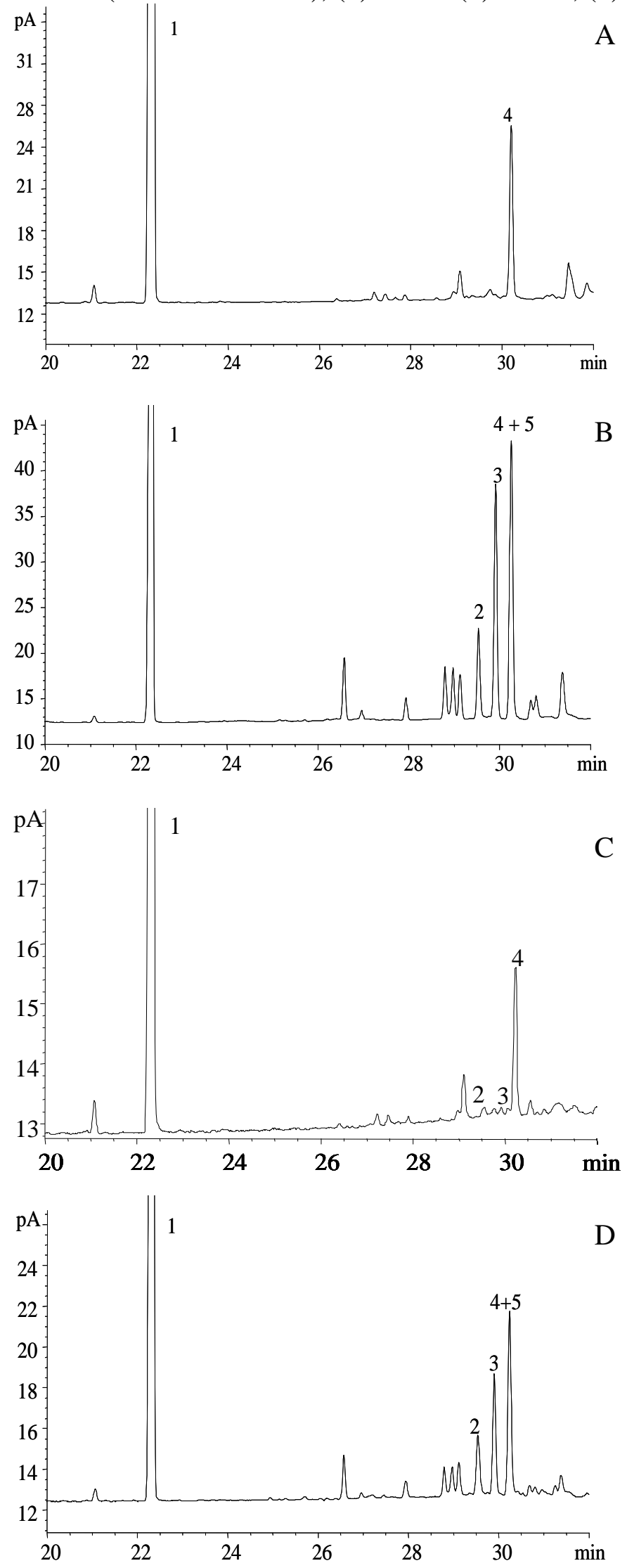
353 Figure 3.- Gas chromatographic profiles of natural roasted (A) and torrefacto roasted 354 coffees (B) and 20 natural : 80 torrefacto coffee blend (C). (1) phenyl $\beta$ - D glucoside 355 (internal standard), (2) DFA7 (3) DFA9, (4) sucrose, (5) DFA10.
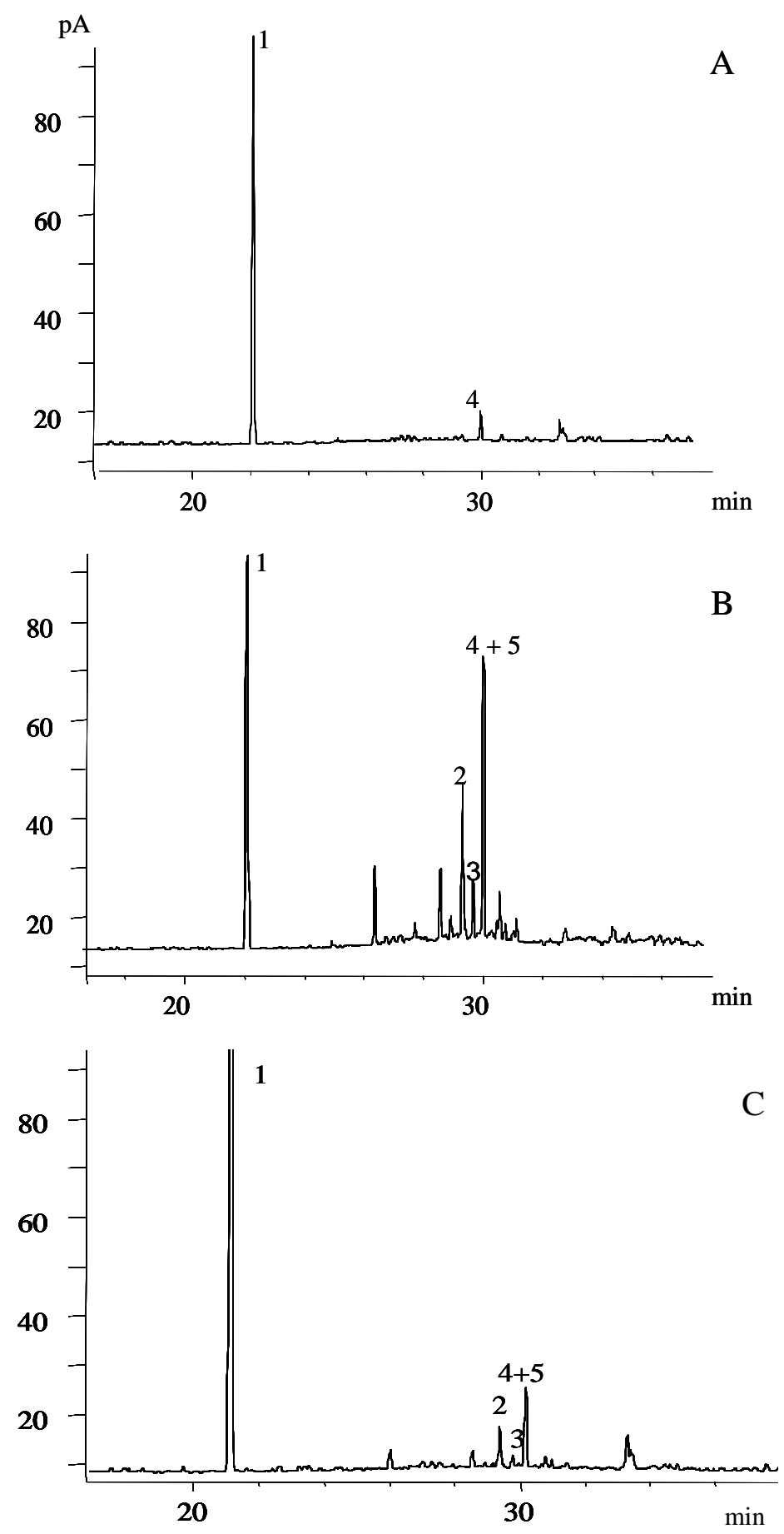